\title{
Pengaruh Edukasi Dengan Simulation Game Terhadap Pengetahuan Ibu Tentang Stunting Di Kecamatan Pemenang Kabupaten Lombok Utara
}

\author{
Hermawati $^{1}$, Sastrawan Sastrawan ${ }^{2}$ \\ Program Studi Magister Administrasidan Kebijakan Kesehatan, Universitas Qamarul Huda \\ Badaruddin ${ }^{1,2}$
}

\begin{abstract}
Abstrak. Balita stunting (pendek) di Indonesia merupakan masalah kesehatan di Indonesia. Prevalensi stunting pada anak usia 12-36 bulan cukup besar mencapai 38,3-41,5\%. Masalah ini perlu untuk segera diatasi karena kejadian stunting pada golden periode dapat menghambat perkembangan otak sehingga menyebabkan penurunan kemampuan intelektual dan produktivitas. Penelitian ini dilakukan di Kecamatan Pemenang, Kabupaten Lombok Utara. Desain penelitian yang digunakan adalah penelitian quasi eksperimen one group pre-pos test design. Jumlah sampel dalam penelitian ini sebanyak 37 orang yang diambil dengan menggunakan teknik simplerandom sampling, dan hasil penelitian ini di analisis mengunakan uji paired t-test. Nilai rata-rata skor pengetahuan ibu tentang stunting sebelum diberikan perlakuan berupa penyuluhan dengan metode simulation game adalah 16,14 dan nilai rata-rata tingkat pengetahuan ibu sesudah perlakuan sebesar 25,05. Peningkatan nilai rata-rata mencapai 8,9 yang menunjukkan adanya peningkatan pengetahuan sebelum dan sesudah perlakuan Uji paired t-test menunjukkan $\mathrm{p}$ value 0,000 menunjukkan perbedaan yang ada bermakna secara statistik. Penelitian ini membuktikan adaya pengaruh pemberian penyuluhan dengan metode simulation game terhadap tingkat pengetahuan ibu tentang stunting di Posyandu Dusun Terengan Kecamatan Pemenang Kabupaten Lombok Utara. Dengan kata lain, metode penyuluhan dengan simulation game merupakan metode penyuluhan yang efektif dalam meningkatkan pengetahuan ibu tentang stunting.
\end{abstract}

\section{Kata Kunci; Edukasi, Simulation Game, Pengetahuan Ibu Tentang Stunting}

\section{PENDAHULUAN}

Balita stunting (pendek) di Indonesia merupakan masalah kesehatan di Indonesia. Kejadian stunting sering dijumpai pada anak usia 12-36 bulan dengan prevalensi sebesar 38,3-41,5\%. Menurut WHO (2010), Indonesia masuk dalam kategori wilayah dengan masalah stunting yang tinggi (30-39\%). Hal tersebut dikarenakan prevalensi stunting di Indonesia pada tahun 2018 mencapai angka 30,8\%6. Tingginya angka balita stunting di Indonesia menandakan bahwa hal tersebut masih menjadi permasalahan kesehatan nasional. Selain itu gangguan pertumbuhan yang tidak sesuai dengan umur mengindikasikan kejadian jangka panjang serta merupakan dampak akumulatif dari ketidakcukupan konsumsi zat gizi, kondisi kesehatan yang buruk pada 1.000 hari pertama kehidupan dan pengasuhan yang tidak memadai (Aridiyah, Rohmawati, \& Ririanty, 2015).

Menurut WHO, prevalensi balita stunting menjadi masalah kesehatan masyarakat jika prevalensinya $20 \%$ atau lebih. Prevalensi balita stunting di dunia sebesar $22,9 \%$ dan di Asia Tenggara sebesar 33,8\% (WHO, 2016).
Indonesia tergolong dalam urutan ketiga besar Negara dengan prevalensi stunting yang tinggi pada tahun 2018, rata-rata balita pendek dan sangat pendek sebesar 37,2\% (WHO, 2019).

Angka prevalensi kejadian stunting di NTB masih tercatat sebesar 33,5\%. Angka ini dinilai lebih baik dari pada tahun sebelumnya, namun masih berada diatas angka nasional yakni sebesar 29,6\%.Balita stunting di NTB tahun 2018 tercatat sebanyak 82.812 balita, dengan kasus tertinggi di Kabupaten Lombok Timur sebesar 43,52\%, diikuti Kabupaten Dompu $33,84 \%$, Lombok Barat sebesar 33,61\%, Kabupaten Bima dan Kota Bima masing-masing 32,01 persen, Sumbawa 31,53 persen, Lombok Tengah 31,05 persen, Lombok Utara 29,30 persen, Kota Mataram 24,49 persen dan terendah Kabupaten Sumbawa Barat 18,32 \% (Dinas Kesehatan Provinsi NTB, 2020).

Program yang diluncurkan Pemerintah Kabupaten Lombok Utara belum maksimal dalam menekan angka stunting di Kabupaten Lombok Utara. Intervensi spesifik dan sensitive yang dilakukan belum memberikan hasil yang 
diharapkan dalam kaitannya dengan penanganan stunting di Kabupaten Lombok Utara.

Peningkatan pengetahuan masyarakat terkait stunting merupakan ujung tombak yang nantinya akan mengubah perilaku masyarakat dalam mencegah dan menangani kejadian stunting di Kabupaten Lombok Utara (Dinkes KLU, 2020)

Penelitian yang dilakukan oleh Olsa, Sulastri, \& Anas (2017) menyatakan bahwa keluarga yang mengalami stunting paling banyak pada anak dengan tingkat pengetahuan ibu yang kurang, Seorang ibu yang memiliki pengetahuan dan sikap gizi yang kurang akan sangat berpengaruh terhadap status gizi anakya dan akan sukar untuk memilih makanan yang bergizi untuk anak dan keluarganya. Dalam meningkatkan pengetahuan masyarakat Pemerintah perlu menerapkan program yang tepat dan sesuai dengan sasaran dan keadaan masyarakat. metode simulation game kemungkinan dapat menjadi solusi yang efektif dalam meningkatkan pengetahuan masyarakat tentang stunting di Kecamatan Pemenang Kabupaten Lombok Utara. Untuk itu, peneliti melakukan penelitian ini dalam rangka menganalisa efektivitas metode simulation game untuk membantu peningkatan pengetahuan pada ibu.

\section{METODE}

Penelitian ini dilakukan di Kecamatan Pemenang, Kabupaten Lombok Utara. Desain penelitian yang digunakan dalam penelitian ini adalah penelitian Quasi Eksperimen. Bentuk perlakuan yang diberikan adalah berupa penyuluhan dengan simulation game menggunakan ular tangga. Penelitian ini dilakukan pengukuran dua kali yaitu sebelum dan sesudah perlakuan. Tingkat pengetahuan sebelum diberikan perlakuan diukut dengan menggunakan kuesioner pengetahuan tentang stunting yang terdiri dari 24 pertanyaan. Selanjutnya, instrumen yang sama digunakan untuk mengukur tingkat pengetahuan sample setelah diberikan perlakuan. Hasil pengukuran dianalisa dengan menggianakan uji paired t-test menggunakan SPSS versi 16

Populasi pada penelitian ini adalah kelompok Ibu dengan balita stunting di Dusun Terengan, Desa Pemenang Barat, Kecamatan Pemenang, Kabupaten Lombok Utara. Jumlah sampel dalam penelitian ini sebanyak 37 orang yang diambil dengan menggunakan teknik simple random sampling

\section{HASIL}

Hasil penelitian ini menunjukan tingkat pengetahuan ibu sebelum dan sesudah diberikan intervensi menunjukan adanya perubahan yang disajikan pada tabel berikut:

Hasil pengukuran tingkat pengetahuan ibu sebelum diberikan Intervensi Menggunakan Teknik Simulation Game (Pre test)

\begin{tabular}{|l|c|c|c|}
\hline Variabel & Mean & n & SD \\
\hline Pretest & 16,14 & 37 & 2,820 \\
\hline
\end{tabular}

Rata-rata tingkat pengetahuan ibu di Kecamatan Pemenang tentang stunting sebelum diberikan metode Simulation Game (SIG) sebesar 16,14 atau kategori pengetahuan kurang.

Setelah diberikan Intervensi Menggunakan Teknik Simulation Game (Post test)

\begin{tabular}{|l|c|c|c|}
\hline Variabel & Mean & n & SD \\
\hline Post test & 25,5 & 37 & 1,563 \\
\hline
\end{tabular}

Rata-rata tingkat pengetahuan ibu di Kecamatan Pemenang tentang stunting setelah diberikan metode Simulation Game (SIG) sebesar 25,05 atau kategori pengetahuan baik.

\section{Data Statistik}

\begin{tabular}{|c|c|c|}
\hline & Postest & Postest \\
\hline$\longrightarrow$ Mean & 16.14 & 25.5 \\
\hline$\longrightarrow$ Median & 16 & 25 \\
\hline$\longrightarrow$ Modus & 16 & 25 \\
\hline Range & 8 & 5 \\
\hline$\Longrightarrow$ Min & 14 & 23 \\
\hline Max & 22 & 28 \\
\hline$\Longrightarrow$ SD & 2.83 & 1.56 \\
\hline
\end{tabular}


Analisis Tingkat Pengetahuan Ibu Sebelum dan Setelah diberikan Intervensi Menggunakan Teknik Simulation Game (Pre test-Post test)

\begin{tabular}{|l|c|c|c|c|}
\hline Variabel & Mean & n & SD & P Value \\
\hline Pre test & 16,14 & 37 & 2,820 & \multirow{2}{*}{0,000} \\
\cline { 1 - 4 } Post test & 25,5 & 37 & 1,563 & \\
\hline
\end{tabular}

Hasil uji statistik, dapat diperoleh nilai rata-rata tingkat pengetahuan ibu tentang stunting sebelum diberikan penyuluhan dengan metode simulation game, dapat diperoleh nilai rata-rata tingkat pengetahuan ibu sebesar 16,14 dan nilai rata-rata tingkat pengetahuan remaja sesudah pemberian metode simulation game sebesar 25,05. Nilai rata-rata tingkat pengetahuan ibu menunjukan adanya peningkatan pengetahuan setelah diberikan penyuluhan dengan metode Simulation Game $(S I G)$ sebesar 8,9 dengan p value $0,000<\alpha=$ 0,05 yang berarti ada pengaruh yang signifikan pemberian penyuluhan dengan metode Simulation Game (SIG) terhadap peningkatan pengetahuan ibu tentang stunting.

\section{PEMBAHASAN}

Berdasarkan hasil analisis menunjukan adanya peningkatan pengetahuan ibu setelah diberikan penyuluhan dengan metode Simulation pemberian penyuluhan dengan metode Simulation Game (SIG) terhadap peningkatan pengetahuan ibu tentang stunting.

Penelitian ini diperkuat Oleh penelitian yang dilakukan oleh Azizah, Amelia, \& Dewi, (2018) yang menunjukan ada pengaruh simulation game terhadap peningkatan pengetahuan remaja putri di SMK Negeri 1 Pujon. Peningkatan pengetahuan remaja dengan metode simulation game diakibatkan belajar dengan metode ini dapat menghilangkan keseriusan dan remaja bias belajar sambil bermain dan menyenangkan, sehingga materi yang disampaikan lebih mudah dicerna dibandingkan dengan metode lainnya

Penelitian ini didukung juga oleh Rizki (2012) yang menunjukan ada pengaruh pemberian simulation game terhadap tingkat penegetahuan remaja. Penelitian serupa dilakukan oleh Yulianti (2020) yang menunjukan ada pengaruh pemberian Simulation game terhadap tingkat pengetahuan remaja di Desa Puyung Kecamatan Jonggat Kabupaten Lombok Tengah.

Adanya peningkatan pengetahuan Ibu tentang stunting di Kecamatan Pemenang Kabupaten Lombok Utara, dikarenakan pemberian penyuluhan dengan menggunakan metode simulation game membuat ibu-ibu dengan balita stunting lebih rileks dan santai dalam menerima materi yang diberikan, dalam proses penyuluhan ibu-ibu sangat antusias dalam menerima materi dan berlomba-lomba untuk menjawab pertanyaan yang diberikan oleh pemateri.

Penelitian yang dilakuakan Rahayu \& Khairiyati (2014) menunjukan Ibu yang memiliki tingkat pengetahuan gizi kategori rendah memiliki baduta yang mengalami stunting yaitu sebesar 92,3\%. Menurut Wulandari \& Muniroh (2020) tingkat pengetahuan ibu merupakan faktor resiko kejadian stunting pada balita, karena rendahnya pengetahuan ibu mengenai gizi dan kesehatan sebelum saat kehamilan dan setelah ibu melahirkan merupakan salah satu faktor penyebab stunting pada balita, sedangkan jika ibu memiliki tingkat pengetahuan yang baik memiliki peluang 0,26 kali menurunkan resiko kejadian stunting dibandingkan balita dengan ibu pengetahuan kurang, karena ibu yang memiliki pengetahuan baik akan memberikan makanan sesuai dengan zat gizi yang diperlukan oleh balita, sehingga balita tidak mengalami kekurangan asupan makanan (Ni'mah \& Muniroh, 2015)

\section{KESIMPULAN}

penelitian ini menemukan adanya pengaruh pemberian penyuluhan dengan metode simulation game terhadap tingkat pengetahuan ibu tentang stunting di Kecamatan Pemenang Kabupaten Lombok Utara, metode penyuluhan dengan simulation game merupakan metode penyuluhan yang efektif dalam meningkatkan 
pengetahuan ibu tentang stunting, dikarenakan dengan metode ini ibu dapat menerima dan mencerna materi dangan baik dan menyenangkan.

\section{SARAN}

Perlunya peningkatan pengetahuan ibu tentang stunting, sebagai salah satu bentuk komitmen pemerintah dalam melakukan penanggulangan stunting di Kabupaten Lombok Utara, dan menjadikan metode simulation game sebagai salah satu metode penyuluhan atau edukasi dalam meningkatkan pengetahuan ibu balita stunting.

\section{DAFTAR PUSTAKA}

Aridiyah, F. O., Rohmawati, N., \& Ririanty, M. (2015). Faktor-Faktor Yang Mempengaruhi Kejadian Stunting Pada Anak Balita Di Wilayah Pedesaan Dan Perkotaan ( The Factors Affecting Stunting On Toddlers In Rural And Urban Areas ). E-Jurnal Pustaka Kesehatan, 3(1).

Azizah, A. H. N., Amelia, C. R., \& Dewi, M. (2018). Perbedaan Pengaruh Metode Simulation Game ( Sig ) Dengan Audio Visual Terhadap Peningkatan Pengetahuan Kesehatan Reproduksi Remaja Putri Di Smk Negeri 1 Pujon. Journal Of Issues In Midwifery, 2(2), $1-11$.

Dinas Kesehatan Provinsi Ntb. Profil Kesehatan Ntb 2020 (2020).

Dinkes Klu. (2020). Program Intervensi Gizi Sensitif Dan Intervensi Gizi Spesifik Kabupaten Lombok Utara. Lombok Utara.

Ni'mah, C., \& Muniroh, L. (2015). Hubungan Tingkat Pendidikan, Tingkat Pengetahuan Dan Pola Asuh Ibu Dengan. Media Gizi Indonesia, 10(1), 84-90.

Olsa, E. D., Sulastri, D., \& Anas, E. (2017). Artikel Penelitian Hubungan Sikap Dan Pengetahuan Ibu Terhadap Kejadian Stunting Pada Anak Baru Masuk Sekolah Dasar Di Kecamanatan
Nanggalo. Jurnal Kesehatan Andalas, 6(3), 523-529.

Rahayu, A., \& Khairiyati, L. (2014). Risiko Pendidikan Ibu Terhadap Kejadian Stunting Pada Anak 6-23 Bulan (Maternal Education As Risk Factor Stunting Of Child 6-23 Months-Old). Penel Gizi Makan, 37(2), 129-136.

Rizki, N. Aditya. (2012). Motode Focus Group Discussion Dan Simulation Game Terhadap Peningkatan Pengetahuan Kesehatan Reproduksi. Jurnal Kesehatan Masyarakat, 8(16), 23-29.

Who. (2019). Stunting Prevalence Among Children Under 5 Years Of Age (\%) (Jme). Jenawa.

Wulandari, R. C., \& Muniroh, L. (2020). Orangtua Dengan Kejadian Stunting Pada Balita Di Wilayah Kerja Puskesmas Tambak Wedi Surabaya Correlation Between Adequacy Levels Of Nutrition, M Other' S Knowledge Level, And Height Of Parents With The Incidence Of Stunting In Toddler In Puskesmas Tam. Amerta Nutr, 4(2), 95-102.

Https://Doi.Org/10.20473/Amnt.

Yulianti, S. (2020). Pengaruh Metode Simulation Game ( Sig ) Terhadap Tingkat Pengetahuan Remaja. Jurnal Ilmu Sosial Dan Pendidikan, 4(3), 1620. 